\title{
Etiske utfordringer med non-invasive prenatale tester (NIPT)
}

\author{
Bjorn Hofmann ${ }^{1}$
}

Seksjon for helse, teknologi og samfunn, Høgskolen i Gjøvik, bjoern.hofmann@hig.no /

Senter for medisinsk etikk, Institutt for helse og samfunn, Universitetet i Oslo, b.m.hofmann@medisin.uio.no

Analyser av cellefritt DNA fra foster i gravide kvinners blod gir nye muligheter innen fosterdiagnostikk: Testene er bedre enn eksisterende tester, de reduserer risikoen og er billigere. Flere land har tatt i bruk disse testene, og Helsedirektoratet i Norge har mottatt søknad om å ta $i$ bruk en test som erstatter tidlig ultralyd og blodprøver. Likevel nøler norske myndigheter. Hvorfor gjør de det? Ett av svarene er at non-invasive prenatale tester fører med seg en rekke faglige og moralske spørsmål og gir flere grunnleggende etiske utfordringer. Denne artikkelen gjennomgår et bredt knippe av de utfordringene som NIPT reiser. Hensikten er å synliggjøre hvorfor NIPT påkaller etisk refleksjon og å bidra til en åpen debatt og en transparent beslutningsprosess. Artikkelen identifiserer fem sentrale og konkrete spørsmål for vurderingen av NIPT.

Nøkkelord: non-invasiv prenatal diagnostikk, testing, fravalg, foster, blodprøve, ekspressivisme, statsliberalt dilemma, dilemma, abort, retten til ikke å vite

\section{English summary: Ethical challenges with non-invasive prenatal tests (NIPT)}

Non-invasive prenatal testing (NIPT) performed with the use of massively parallel sequencing of cell-free DNA (cfDNA testing) in maternal plasma gives extended possibilities in prenatal screening. The tests are claimed to be better than existing alternative tests, they reduce the risk, and it is claimed they are cheaper. They have been used in several countries since 2012, and the University Hospital of North Norway has applied to the Directorate of Health to replace first trimester ultrasound and plasma screening with NIPT. The Directorate of Health is reluctant to reply. Why is this? One of the answers may be that NIPT raises a series of professional and moral questions, and poses profound ethical challenges. This article reviews a series of the challenges with NIPT. The aim is to highlight why NIPT calls for ethical reflection and to contribute to an open debate and a transparent decision-making process. The article identifies five major questions to address in the assessment of NIPT: What are the criteria for screening and removing certain conditions? How certain do we have to be that these conditions do appear in living children? How should we handle information from NIPT for living persons? How can we avoid that persons with the conditions that are selected for screening and removal are insulted, stigmatized, or discriminated? How can we avoid that systematic screening and removal of fetuses with certain conditions develop norms and values that breach with basic social or ethical principles? 
Keywords: non-invasive prenatal testing (NIPT), diagnostics, blood tests, fetus, abortion, moral status, expressivism, the right not to know

\section{Innledning}

It is probable that non-invasive prenatal diagnosis using foetal DNA in maternal plasma would play an increasingly important role in the future practice of prenatal testing. However, it is important to address the ethical, legal and social issues surrounding such developments. (Lo 2012:3) ${ }^{2}$

Kvinners blod har vært gjenstand for oppmerksomhet og interesse i århundrer - både kulturelt og vitenskapelig (Bondevik \& Lie 2012). Nye såkalte non-invasive prenatale tester (NIPT) av gravide kvinners blod gjør det mulig å analysere fosterets egenskaper. Dette utvider blodets betydning ytterligere. Samtidig sprenger det grensene for hva man har trodd var mulig å forutse om fostre. Helt fra oldtiden har man forsøkt å forutsi og påvirke fosterets egenskaper. I antikken prøvde man eksempelvis å bestemme fosterets kjønn ved utføre samleie på bestemte måter og i gitte himmelretninger. NIPT virkeliggjør derfor flere tusen år gamle aspirasjoner. ${ }^{3}$

I 1997 demonstrerte Lo og medarbeidere (Lo et al. 1997) at det var mulig å finne føtalt DNA i kvinnens blod fra uke $5 \mathrm{og}$ frem til fødselen (Lo et al. 1998). Analyser av cellefritt føtalt DNA eller RNA fra gravide kvinners blod gjør det i dag mulig å fastslå kjønn, gjøre analyser av kromosomavvik, slik som trisomi 21, 18 og 13, samt gjøre rhesusbestemmelse av kvinnen og fosteret for å forhindre blodmangel hos fosteret og vaksinere kvinnen. Det er også mulig å gjøre hel-genomanalyser av fosteret (Fan et al. 2012; Lo et al.1997; 1998; 2010; Kitzman et al. 2012; Papageorgiou \& Patsalis 2013).

NIPT kan gjøres innenfor grensen for selvbestemt abort, og studier viser at nøyaktigheten for kjønnsbestemmelse er høy (Wright et al. 2012). Det samme gjelder deteksjon av trisomi 21, 18 og 13 (Morain, Greene \& Mello 2013), se tabell 1. 
Tabell 1 Noyaktigheten til ulike tester ut fra opplysninger i Morain, Greene \& Mello (2013)

\begin{tabular}{|c|c|c|c|c|c|c|}
\hline Test & Firma & $\begin{array}{l}\text { Lan- } \\
\text { sert i } \\
\text { USA }\end{array}$ & Tilstander & $\begin{array}{c}\text { Kost- } \\
\text { nad } \\
\text { (USD) }\end{array}$ & $\begin{array}{c}\text { Sensiti- } \\
\text { vitet } \\
(\%)\end{array}$ & $\begin{array}{c}\text { Spesifi- } \\
\text { sitet } \\
(\%)\end{array}$ \\
\hline Verifi & Verinata & 02.2012 & $\begin{array}{l}\text { Trisomier 21, } 18 \text { og } 13 \text {; } \\
\text { kan oppdage unor- } \\
\text { male kjønnskromoso- } \\
\text { mer (monosomi X, } \\
\text { XXX, XXY og XYY) } \\
\text { og kan bidra til a } \\
\text { vurdere risikoen ved } \\
\text { X-bundne tilstander } \\
\text { (hemofili, } \\
\text { Duchennes muskel- } \\
\text { dystrofi og tvetydige } \\
\text { genitalia) }\end{array}$ & 1200 & $\begin{array}{l}\text { Trisomi 21: } \\
>99,9 ; \\
\text { trisomi 18: } \\
97,4 ; \\
\text { trisomi } 13 \text { : } \\
87,5\end{array}$ & $\begin{array}{l}\text { Trisomi 21: } \\
99,8 ; \\
\text { trisomi 18: } \\
99,6 ; \\
\text { trisomi 13: } \\
>99,9\end{array}$ \\
\hline $\begin{array}{l}\text { Materni } \\
\text { T21 }\end{array}$ & $\begin{array}{l}\text { Seque- } \\
\text { nom }\end{array}$ & 10.2011 & $\begin{array}{l}\text { Trisomi } 21,18 \text { og } 13 \text {; } \\
\text { kjønnsbestemmelse }\end{array}$ & 2762 & $\begin{array}{l}\text { Trisomi 21: } \\
99,1 ; \\
\text { trisomi 18: } \\
>99,9 ; \\
\text { trisomi } 13 \text { : } \\
91,7\end{array}$ & $\begin{array}{l}\text { Trisomi 21: } \\
99,9 \text {; } \\
\text { trisomi } 18 \text { : } \\
99,6 \text {; triso- } \\
\text { mi 13: } 99,7\end{array}$ \\
\hline $\begin{array}{l}\text { Harmo- } \\
\text { ny }\end{array}$ & Ariosa & 05.2012 & Trisomi 21,18 og 13 & 795 & $\begin{array}{l}\text { Trisomi 21: } \\
>99,9 ; \\
\text { trisomi 18: } \\
98,1 ; \\
\text { trisomi 13: } \\
80,0\end{array}$ & $\begin{array}{l}\text { Trisomi 21: } \\
>99,0 ; \\
\text { trisomi 18: } \\
>99,0 ; \\
\text { trisomi } 13: \\
>99,0\end{array}$ \\
\hline $\begin{array}{l}\text { Panora- } \\
\text { ma }\end{array}$ & Natera & 12.2012 & $\begin{array}{l}\text { Trisomi 21, } 18 \text { og } 13 \text {; } \\
\text { monosomi X; forven- } \\
\text { tet oppdagelse av ek- } \\
\text { stra } \\
\text { kjønnskromosomer } \\
(\mathrm{XXX}, \mathrm{XXY} \text { og XYY) }\end{array}$ & 1495 & $\begin{array}{l}\text { Trisomi 21: } \\
100 ; \\
\text { trisomi 18: } \\
100 ; \\
\text { trisomi } 13: \\
100\end{array}$ & $\begin{array}{l}\text { Trisomi 21: } \\
100 \text {; } \\
\text { trisomi 18: } \\
100 \text {; } \\
\text { trisomi 13: } \\
100\end{array}$ \\
\hline
\end{tabular}

NIPT er allerede i bruk i en rekke land, og flere firmaer tilbyr nå også postordresett for å teste for fosterets kjønn med en dråpe blod fra fingeren (Wright et al. 2012). Flere kommersielle tester, som inkluderer tester for (risiko for) en rekke sykdommer, og for desentralisert (point of care) analyse (ANGELAB 2012), er under utvikling.

Universitetssykehuset i Nord-Norge (UNN) har søkt Helsedirektoratet om å ta i bruk NIPT av gravide kvinners blod for å finne kromosomavvik. De ønsker å erstatte kombinert ultralyd og blodtest (KUB) ${ }^{4}$ med NIPT fordi denne testen er mer nøyaktig, og fordi man kan unngå risikofylte invasive tester, slik som fostervannsprøve og morkakeprøve. 
Testen kan tas tidlig i svangerskapet (innenfor grensen for selvbestemt abort). Belastningene for kvinnen kan reduseres, eksempelvis ved at abort tas tidligere. Dessuten kan det tenkes at NIPT kan omgå den fastlåste debatten om KUB.

Som et ledd i sin behandling har Helsedirektoratet bedt Bioteknologinemnda om en uttalelse, men det har tatt tid å oppnevne ny nemnd. I en foreløpig behandling i den gamle nemnda kom man frem til at «det er umulig å si nei til en metode som synes å være mer treffsikker og har mindre risiko, og som attpåtil er kostnadseffektiv» (Skogstrøm 2013). En spørreundersøkelse InFact gjorde for avisen Dagen viste at 55,5 prosent av de spurte mente at blodtesten bør tillates (NTB 2013). «Dette er ikke overraskende, i og med at vi allerede langt på vei har åpnet for en mer aggressiv diagnostikk av disse tilstandene gjennom forbedret teknologi og aksept av tidlig ultralyd», uttalte Reidun Førde, professor i medisinsk etikk ved Universitetet i Oslo, til Aftenposten (NTB 2013). Den nye testen kan bli vanskelig å stoppe og kan i tillegg fjerne det kontroversielle alderskriteriet for fosterdiagnostikk på 38 år, hevder Berge Solberg, professor i medisinsk etikk ved NTNU (Skogstrøm 2013). Dessuten kan vi spare penger (Salvesen 2014).

Vi har altså en ny test som er mer nøyaktig enn eksisterende tester, som har mindre risiko, er mer kostnadseffektiv og som kan unngå betente spørsmål. Likevel nøler myndighetene og ber Kunnskapssenteret om en full kunnskapsoppsummering (Helsedirektoratet 2013). Hvorfor gjør de det?

Det synes å være flere grunner til det. For det første er det faglig uenighet om hvor nøyaktige testene er for den gruppen den ønskes brukt til. For det andre følger det moralske utfordringer med å skille mellom svangerskapsomsorg og fosterdiagnostikk, hvilke tilstander man skal søke etter (og fjerne), og hvordan man kan implementere testene uten å diskriminere eller stigmatisere de som har tilstandene som det søkes etter (og som fjernes). I tillegg rører den nye testen ved noen grunnleggende etiske utfordringer knyttet til moderne fosterdiagnostikk, slik som moralsk status og abort. Jeg skal i denne artikkelen redegjøre for de etiske utfordringene ved NIPT som kan antyde hvorfor helsemyndighetene nøler. Det kan være gode grunner til å tenke seg grundig om før man bestemmer seg for om og eventuelt hvordan man skal innføre testene.

\section{Hvem blir berort?}

Før vi ser på de faglige og etiske utfordringene, kan det være klokt å gjøre rede for hvem som berøres av testene som den nye metoden muliggjør. Gravide kvinner er åpenbart berørt. Det samme gjelder partnerne deres og helsepersonell som skal henvise og gjennomføre testene, som skal veilede kvinnene (paret), samt de som skal iverksette følgene av deres beslutninger og ivareta dem i denne prosessen. I tillegg berøres personer som føler seg fornærmet, støtt, krenket eller diskriminert som følge av at tilstander de har, oppfattes som mindre verdt («abortgrunn»), og som frykter at de kan bli isolert og ensomme («utrydningstruet»). Samfunnet blir berørt gjennom de ressursene som allokeres, og gjennom normer og verdier som formes ved innføringen av teknologien. Fremti- 
dige barn vil også berøres, i den grad kunnskap om deres genetiske egenskaper vil være tilgjengelig hos tredjepart (helsevesenet og foreldrene).

I fremtiden vil også donorer (ved eggdonasjon, mitokondriedonasjon og embryodonasjon) og bestiller (ved surrogati) kunne være involvert da det er «deres» donormateriale som blir testet og eventuelt fjernet. Divergerende interesser vil kunne gi opphav til konflikter.

\section{Faglige utfordringer: Er testen god nok?}

Et av de faglige spørsmålene, som har klare moralske implikasjoner, er hvorvidt testen er god nok. Som gjengitt i tabell 1 viser flere studier at testenes nøyaktighet for å oppdage trisomier $(21,18,13)$ er høy. Samtidig peker kritikere på at den dokumenterte nøyaktigheten stammer fra studier som ikke er gjennomført på normalbefolkningen, men på befolkningsgrupper med høy forekomst av aneuploidier (Morain, Greene \& Mello 2013). Selv om sensitivitet og spesifisitet i prinsippet skal være uavhengig av prevalens, vil uklare testresultater i en populasjon med høy forekomst av tilstanden oftere tolkes som positive testsvar enn slike tester i populasjoner med lav forekomst. Det kan derfor gi «kunstig høy» nøyaktighet i forhold til hva testen presterer på andre grupper med lavere forekomst av tilstanden det testes for (Morain, Greene \& Mello 2013).

Dessuten oppgir studiene ikke (positiv og negativ) prediktiv verdi for testene. Dette er utfordrende, fordi brukerne av testen trenger å vite hva sannsynligheten er for at et positivt (eller negativt) testsvar for en konkret person er sant (eller falskt). Selv ved bruk av tester med høy sensitivitet og spesifisitet (over 90 prosent) vil positiv prediktiv verdi kunne være langt under 10 prosent hvis det er svært få som har tilstanden i den populasjonen som undersøkes. Ved bruk på lavrisikogrupper vil derfor en ellers god test kunne vise seg å være svært dårlig.

Dersom testenes nøyaktighet er usikker, blir det vanskelig for brukerne av testen og beslutningstagere å vurdere dens egnethet. Det blir vanskelig å gjøre en nytteetisk vurdering. Tilsvarende blir det utfordrende å informere og veilede kvinner og partnere samt å tilfredsstille kravet om informert samtykke.

Dette er faglige og vitenskapelige spørsmål som gir moralske utfordringer. Hvordan skal man handle under usikkerhet? De faglige utfordringene lar seg løse gjennom mer kunnskap om bruk av testene gjennom forskning og evaluering (metodevurdering). ${ }^{5} \mathrm{De}$ representerer derfor ingen prinsipielle problemer. Kunnskapsspørsmålet er åpenbart en av grunnene til at myndighetene ber om en kunnskapsoppsummering før de fatter en beslutning. Når disse er avklart, gjenstår en rekke etiske utfordringer, ${ }^{6}$ som også kan forklare at de nøler. 


\section{Etiske utfordringer med NIPT}

Som teknologi kan NIPT klassifiseres som «fosterdiagnostikk» ut fra sin funksjon (Hofmann 2006) og gjenreiser som dette mange av de etiske spørsmålene ved fosterdiagnostikk generelt. De fleste av disse er bredt og grundig drøftet i litteraturen og har ingen enkle løsninger. De vil derfor bare kort nevnes her. Andre utfordringer har vært mindre fremme i de nordiske landenes debatt, og vil derfor få noe bredere drøfting.

\section{Reproduktive valg}

Kunnskap om egenskapene ${ }^{7}$ til fosteret gir paret mulighet til å ta nye og mer informerte valg (Fan et al. 2013; Nuffield Council on Bioethics 2006) og blir fremhevet som en av fordelene med NIPT (Health Council of the Netherlands 2002; de Jong et al. 2011). Samtidig er valget foreløpig begrenset til eksistens: «Skal fosteret med disse spesifikke genetiske egenskapene få leve og bli vårt barn?» Det reproduktive valg begrenser seg derfor til fravalg av fostre med forventet sykdom og inkluderer ikke tilvalg, eller «designerbabyer» som det retorisk har vært hevdet. Ettersom testene utvikles til å teste for flere tilstander (og eventuelt også hele genomet), vil selvsagt fravalgsmulighetene øke vesentlig. At testene kan gjennomføres innenfor grensen for selvbestemt abort, kan også bidra sterkt til å utvide parenes mulighet til å velge egenskapene fritt. Abortlovens ${ }^{8}$ begrensninger av abort til når det er «stor fare for at barnet kan få alvorlig sykdom» $(\$ 2-c)$, vil ikke lenger virke begrensende på hvilke tilstander og egenskaper man kan fjerne fostre for. Slik utvides den enkeltes (fra)valg av fosterets egenskaper kraftig. NIPT kan derfor bidra til at pars reproduktive valg vil øke vesentlig. Vi har lett for å oppfatte valgfrihet som et ubetinget gode, men reproduktive valg har, som andre valg, både positive og negative sider (Dworkin 1982). Konkrete eksempler følger senere.

Fravalg er dessuten løst knyttet til tilvalg. Velger man bort et foster som ville blitt en gutt, så velger man samtidig å få en jente. Tilvalgsmulighetene er likevel sterkt begrenset, siden handlingsvalget (foreløpig) er begrenset til å fjerne fosteret. Per i dag har man ikke mange nok fostre å velge blant til at man reelt kan velge seg kombinasjoner av egenskaper. Tilvalgsmulighetene vil derfor foreløpig være sterkt begrensede. Utstrakt bruk av eggsanking og frysing («social freezing») vil kunne endre dette i fremtiden.

I tillegg er muligheten til å informere om alle tenkelige følger av en test begrenset. Hver tilstand som inkluderes i testen, vil ha sine egenskaper og usikkerheter (penetrans og ekspressivitet), og testen vil ha sine karakteristika, forutsetninger og begrensninger. Testenes betydning vil i stor grad kunne avhenge av tilleggsinformasjon, som kan være krevende å frembringe eller utfordrende å formidle. Det reelle valget kan derfor begrenses av tilgangen på informasjon og veiledning.

En formell utvidelse av frivillige valg, slik som gjennom et organisert helsetilbud, kan dessuten i praksis begrense enkeltindividers valgmulighet (van den Heuvel et al. 2010). Det er godt kjent at screeningprogrammer kan legge føringer i form av «forventede valg» (van den Heuvel et al. 2010). Når et helsetilbud tilbys av den offentlige helsetjenesten, oppfattes dette som en anbefaling av tilbudet. Mulighetene som gjøres tilgjengelig, oppfattes som tilrådinger (Press 2000), og testene peker mot valg av abort (Solberg 2008). 
Ikke å følge «anbefalingene» kan oppfattes som problematisk og gjøre de(n) enkelte ansvarlig. Dessuten kan enkel testing føre til økt testing (Newson 2008). Det kan igjen føre til at fordelene med testing (som redusert antall spontanaborter som følge av færre invasive tester) spises opp av ulempene når få får oppleve fordelene og mange vil oppleve ulempene (Chitty et al. 2012; Greely 2011). Det gjenstår selvsagt å se om NIPT vil få slike følger, men i vurderinger av om NIPT skal innføres eller tillates, vil man måtte drøfte slike spørsmål. Det er derfor foreløpig uklart om NIPT i praksis vil fremme og utvide selvstendige og informerte valg (Fan et al. 2013; Nuffield Council on Bioethics 2006; de Jong et al. 2011).

Både i diagnostikk og screening er NIPT spesiell, fordi den (i hovedsak) ikke har forebygging eller (tidlig) behandling av sykdom som mål, men munner ut i valget om hvorvidt man skal fjerne fosteret. Godet (reproduktive valg) forutsetter derfor noe som av mange oppfattes som noe negativt (abort). For mange oppveier muligheten til å velge bort fostre med forventet sykdom de (eventuelt) negative sidene ved abort. Men abort er likevel et relevant moralsk spørsmål og en etisk utfordring ved NIPT.

\section{Det vanskelige abortspørsmålet}

Resultatet av NIPT er et svar som antyder om fosteret har (genetiske) egenskaper knyttet til sykdom. Så langt finnes det få behandlingsmuligheter av fosteret som kan forhindre at barnet får den relaterte sykdommen, og abort er, som nevnt, det eneste alternativet til å la fosteret utvikles til et barn (som eventuelt får den aktuelle sykdommen). I motsetning til andre helsetiltak og screeningprogrammer har NIPT ikke helse som mål (Health Council of the Netherlands 2008). Selv om det er rimelig bred enighet om at abort er drap av biologisk liv, er det stor uenighet om betydningen av dette. «Når får fosteret moralsk status?», er det etiske kjernespørsmålet. Mens enkelte mener at det er ved unnfangelsen, mener andre at det er ved fødselen (eller senere). Lovgivingen i Norden tar stort sett utgangspunkt i en graduell forståelse av moralsk status, der fosteret tillegges økende rett til beskyttelse utover i svangerskapet. Utfordringen for ikke-absolutte perspektiver (slik som ved graduell moralsk status) er å sette grenser og begrunne dem.

\section{Hvilke tilstander? Fravalgets etikk}

Et annet vanskelig spørsmål NIPT reiser, er hvilke egenskaper man skal teste for. Foreløpig er det i Norge foreslått å teste for tilstander som man allerede tester for ved KUB, men det pågår en rask utvikling, der stadig flere tilstander inkluderes i testene. Konkurransen mellom testtilbydere er stor, og det ser ut til at de som kan tilby de mest omfattende testene, vil vinne markedsandeler og kunne utvikle de beste testene. Å angi hvilke tilstander som det skal testes for, er et moralsk spørsmål med betydelige etiske utfordringer. Også dersom vurderingene er avgrenset til «alvorlige tilstander», reiser det spørsmål om hva som menes med «alvorlig», og hvem tilstanden er alvorlig for. Alvorlighet vurderes gjerne ut fra smerte, lidelse, redusert levetid og funksjonsnedsettelse, men også behandlingsmulighet og alder ved sykdomsdebut spiller inn. Alle disse elementene gir vanskelige vurde- 
ringer. Hvem som skal vurdere alvorlighet, er også utfordrende. Det er godt kjent at pårørende oppfatter tilstander langt mer alvorlig enn personer som har dem, og at funksjonshemmede selv ikke tenker over sin egen tilstand i dagliglivet (Asch 2000). Dessuten kan en 90-åring oppfatte en gitt tilstand som like ille som en tolvåring gjør.

Valg av tilstander det skal testes for, reiser altså moralske spørsmål, og begrunnelsene for valget gir etiske utfordringer. Samtidig baserer advarslene mot en «utglidning» til stadig mildere tilstander seg på skråplansargumentet. Man er eksempelvis bekymret for at man vil teste for stadig mer moderate tilstander og for sosialt relaterte egenskaper. Vil eksempelvis alle (som kvalifiserer til begrensede invasive tester) testes for alle mulige egenskaper (Wright 2009)? Skråplansargumentet er problematisk, blant annet fordi det kan brukes til å stanse all utvikling, og fordi det forutsetter at vi ikke evner å sette grenser (Holm \& Takala 2007).

På den annen side argumenteres det for at NIPT nettopp bør brukes på andre grupper, eksempelvis for kvinner med mindre risiko for å få barn med utviklingsavvik (under 38 år) (Skogstrøm 2013). Her forutsetter man at NIPT vil ha minst samme (gode) virkning for denne gruppen som for den gruppen som allerede i dag har et tilsvarende tilbud (KUB). Slike argumenter baserer seg på det som kan kalles «det automatiske fremskrittsargumentet», som speilvender skråplansargumentet. Dette argumentet er like tvilsomt som skråplansargumentet, da det forutsetter det som skal vises og at forbedringer «kommer av seg selv» (Holm \& Takala 2007).

Vurderingen av hvilke tilstander det skal testes for, og hvordan man skal begrunne valget (og eventuelle begrensninger), reiser moralske spørsmål, som beslutningstagere må håndtere. Svarene og løsningene er mange, men ikke enkle.

\section{Erstatter NIPT invasive tester?}

En av fordelene med NIPT, blir det hevdet, er at den kan erstatte invasive tester (Skogstrøm 2013; Hov, Åsberg \& Torstensen 2014). Invasive tester, slik som fostervannsprøve og morkakeprøve, medfører risiko for spontanabort (0,5-1,3 prosent). Dersom NIPT kan erstatte dårligere tester, som ellers må bekreftes med invasive tester, kan en rekke spontanaborter unngås. På grunn av de faglige bekymringene om testens nøyaktighet, drøftet ovenfor, har flere av de store fagsammenslutningene, slik som American Congress of Obstetricians and Gynecologists, The Society for Maternal-Fetal Medicine og National Society of Genetic Counselors, anbefalt å gjøre invasive tester i tillegg (Morain, Greene \& Mello 2013). Dersom NIPT viser seg å være bedre for den gruppen det faktisk brukes for i dag, og den bare brukes for disse, vil antall spontanaborter av ikke-affiserte fostre reduseres, men dersom den anvendes på utvidede grupper, slik det forventes og forlanges (Skogstrøm 2013; Chitty et al. 2012; Greely 2011), kan man få flere spontanaborter enn tidligere. I så tilfelle mister NIPT sin risikoreduserende effekt, og en av de klare fordelene forsvinner. 


\section{Invaderende språk: Invasive eller non-invasive tester?}

Det er også interessant å merke seg at språket kan være moralsk ledende. «Invasiv» kommer av det latinske ordet invāsīon - å trenge inn i eller gjennom. Det kan virke paradoksalt å kalle slike tester non-invasive, når de rent faktisk trenger gjennom kvinnens hud og derfor per definisjon er invasive. I fosterdiagnostikken betraktes fostervannsprøve og morkakeprøve, der man stikker en nål gjennom kvinnens mage (eller skjede) for å ta prøve av fostervannet eller morkaken, som invasive tester. Slike invasive tester er, som nevnt, forbundet med en risiko for spontanabort, og man har derfor ønsket å begrense slike tester til svangerskap med økt risiko.

Å betegne testene av cellefritt DNA som non-invasive gir inntrykk av at de er mindre risikable og mindre invaderende enn de invasive testene. Selv om de er invasive (i kvinnen), og blodprøven av kvinnen neppe er til stor plage, gir det «non-invasive» i navnet testen en positiv klang. Dette kan også være verdiformende og misvisende dersom et resultat av NIPT vil bli flere invasive tester.

\section{Kan NIPT omgå det vanskelige ultralydsporsmålet?}

En fordel med NIPT er altså at testene kan erstatte mer indirekte og unøyaktige metoder, som (tidlig) ultralyd og KUB (de Jong et al 2011; Nepomnyashchaya 2013; Hov, Åsberg \& Torstensen 2014). KUB har vært kontroversielt og skapt betydelig offentlig debatt i Norge. Dersom NIPT er en bedre metode, kan man tenke seg at den kan unngå kontroversene med KUB. Dessverre er det lite som tyder på at NIPT vil fungere som en kontroversløsende (moral)teknologi.

Det er mye prestisje knyttet til KUB. Å fjerne et helsetilbud («desinvestment») er ikke enkelt (Henshall, Schuller \& Mardhani-Bayne 2012). Dessuten brukes KUB i dag for kvinner under 38 år, selv om det formelt ikke er forankret i bioteknologiloven (Røe, Salvesen \& Eggebø 2012). Man kan derfor vanskelig avgrense seg til å erstatte en gammel (og dårlig) teknologi med ny (og bedre) teknologi uten å rydde opp i praksis. Å begrense den nye testen til kvinner over 38 år synes like vanskelig som å begrense dagens test til disse. Dagens praksis undergraver argumentet om at det bare dreier seg om «å erstatte en ny og bedre test med en eksisterende og dårlig test». Dessuten argumenteres det for at NIPT kun kan brukes sammen med og som et supplement til ultralydundersøkelse, fordi NIPT forutsetter at man kan skille ut flerlingsvangerskap (Salvesen 2014).

Dette vanskeliggjør beslutningene, og en av grunnene til at man nøler med å innføre NIPT, er trolig at den reiser de samme grunnleggende spørsmålene som KUB: Hva skal vi søke etter, hvem skal vurdere disse tilstandene, hvilket samfunn får vi dersom vi (u)systematisk fjerner fostre med egenskaper som assosieres med gitte tilstander, og hvilket signal sender vi til personer med slike tilstander? NIPT aktualiserer de vanskelige spørsmålene snarere enn å unngå dem (Hofmann 2013a; 2013c), selv om det gjøres iherdige forsøk på å redusere debatten om NIPT til rent tekniske spørsmål (Salvesen 2014; Hov, Åsberg \& Torstensen 2014). 


\section{Vanskelig kunnskap}

Selve metoden, NIPD, reiser altså spørsmålet om hvor bredt en skal teste, det vil si hvor mange tilstander man skal teste for, og som resultat hvilke tester (NIPT) man skal tillate og tilby. Enkelte hevder at man må teste begrenset og målrettet for enkelte tilstander, mens andre ønsker å teste bredt for å fange opp så mange tilstander som mulig. Uansett vil kunnskapen kunne være vanskelig å håndtere. Smal og målrettet testing vil gi spesifikk kunnskap, som kan virke stigmatiserende og diskriminerende på personer som har tilstandene. Dette vil bli nærmere behandlet nedenfor. Bred testing vil møte kritikk om «lytefrykt» og «genrensning» $\mathrm{i}$ tillegg til at man vil sitte igjen med få fostre som svarer til ens ønsker, behov og reproduktive mål.

Mange av testresultatene er dessuten usikre og byr på vanskelige tolkninger. Når vi kan teste for svært mange og svært ulike tilstander, blir det utfordrende å informere og veilede dem som skal testes, på en skikkelig måte (Rafi \& Chitty 2009). Vi ser allerede i dag at det er vanskelig for kvinner å gi gyldig samtykke til tester for trisomi 21 (Seror \& Ville 2009). Å få gyldig samtykke for NIPT kan derfor bli utfordrende (Newson 2008; Chitty et al. 2012; Geely 2011; Green et al. 2004; Deans \& Newson 2011). Samtykkeproblemet gjør seg også gjeldende i spørsmålet om hvorvidt det enkelte par skal kunne velge å begrense tilstandene det skal testes for, eller skal kunne skjerme seg mot kunnskap om testresultatene, slik at de kan forbli uvitende, og retten til ikke å vite respekteres. Når vi skal innføre en test, må vi vite hvordan informasjonen fra testen skal håndteres. Det er ikke enkelt, særlig ikke når informasjonen angår personer som enda ikke finnes. ${ }^{9}$

\section{Barnets autonomi}

Der hvor fosteret blir et barn, gjelder informasjonen fra NIPT et fremtidig menneske. Helsevesenet og foreldrene har da (tilgang til) sensitiv informasjon om en person som personen selv ikke har mulighet til å styre. Dette gir en rekke grunnleggende utfordringer for autonomi, konfidensialitet og retten til privatliv. Den fremtidige personen kan komme til å mangle viten om og kontroll over viktig informasjon om seg selv samt hvordan denne informasjonen blir brukt av helsetjenesten og andre. Det kan føre til et paradoks der den økte autonomien (i reproduktive valg) hos personer i dag kan redusere autonomien til fremtidige personer. Mer spesifikt reiser NIPT spørsmålet om nåtidige kvinners rettigheter vil redusere fremtidige personers rettigheter, eksempelvis retten til ikke å vite og retten til en åpen fremtid. På den andre siden kan helsetjenesten sitte på informasjon om en person som har kommet frem ved NIPT, og som kan være av betydning for vedkommendes helse, men som kan være vanskelig å informere vedkommende om, eksempelvis av hensyn til deres rett til ikke å vite. En rekke tilstander, som i enkelttilfeller kan være svært alvorlige, kan ha svært variabel penetranse og ekspressivitet, det vil si at det er usikkert om personen vil få synlige tegn på sykdommen, og usikkert hvor alvorlige disse eventuelt er.

Problemstillingene forsterkes av at NIPT utvisker skillet mellom prenatal diagnostikk/screening og prediktive tester (av barn) (de Jong et al. 2011). Informasjon som fremkommer ved styrking av reproduktive valg i den prenatale testen har prediktiv betydning 
for personen som eventuelt fremkommer som et resultat. Informasjonen om barnets genetiske egenskaper kan også føre til at foreldre og andre endrer atferd overfor vedkommende. På samme måte som ultralyd har endret oppfatningen av og forholdet til fostre, vil NIPT kunne endre vårt forhold til fostre og fremtidige barn. NIPT vil også kunne endre vår oppfatning av graviditet og foreldreskap.

Det er selvsagt mulig å regulere lagringen av og tilgangen til informasjon fra NIPT for å sikre privatlivet og autonomien til personer med NIPT-data, men erfaring viser at sikring av helseinformasjon er praktisk utfordrende (Hofmann 2013b; Helse- og omsorgsdepartementet 2013).

\section{Svangerskapsomsorg, fosterdiagnostikk eller screening?}

Et annet spørsmål NIPT reiser, er hvorvidt NIPT er svangerskapsomsorg, fosterdiagnostikk eller screening. Det synes å være forholdsvis bred enighet om at det er uklart om ultralyd er svangerskapsomsorg eller fosterdiagnostikk, siden man under rutineultralyd i svangerskapsomsorgen kan avdekke (risiko for) alvorlige tilstander hos fosteret. Sterke faglige interesser og ønsker i befolkningen har bidratt til at fosterdiagnostikken er trukket inn i svangerskapsomsorgen. I tillegg argumenteres det for at retningslinjene er uklare (Røe, Salvesen \& Eggebø 2012). Når det søkes om å erstatte KUB med NIPT, vil det kunne bidra til, men også fordre, en opprydding på området, siden NIPT tydeligere retter seg mot risiko for bestemte tilstander hos fosteret.

Om det vil gå slik, er et åpent spørsmål. En av grunnene til at man likevel nøler, selv om innføringen av NIPT kan gi en etterlyst (og etterlengtet?) opprydding, er at det er sterke faglige interesser involvert i ultralydaktiviteten i Norge. Ultralyd i svangerskapsomsorgen har blitt innført i Norge på bakgrunn av svært tynt vitenskapelig grunnlag (Bratlid 2007) og ut fra ønsket om å kontrollere en helsefaglig aktivitet som var i ferd med å komme ut av kontroll (Kvande 2008). Det er bygd opp et betydelig fagmiljø som ikke nødvendigvis er begeistret for NIPT. Eksempelvis har forskere og klinikere med forankring i ultralyddiagnostikk og -screening vært ivrige etter å påpeke problemer med NIPT, eller de har påpekt at NIPT må brukes sammen med ultralyd (Nicolaides et al. 2013). Diskusjonen om svangerskapsomsorg, fosterdiagnostikk og (egenskaps)screening er på ingen måte enkel og blir neppe løst med innføringen av NIPT, som erstatning for KUB (Skogstrøm 2013) eller som erstatning for invasive tester (Salvesen 2014; Hov, Åsberg \& Torstenesen 2013).

NIPT gir også andre utfordringer ved at den utvisker skillet mellom prenatal testing og prediktiv testing (av barn) (de Jong et al. 2011) og mellom kollektiv forebygging og omsorg for den enkelte (Health Council of the Netherlands 2008).

\section{Samfunnets signaler}

De enkeltes (fra)valg av fostre er ganske sikkert motivert ut fra deres reproduktive valg og legitime ønsker om friske barn og ikke ut fra ønsket om å redusere antall personer med bestemte egenskaper i samfunnet (Parens \& Asch 2000). Likevel er dette resultatet 
(Ekelund et al. 2008). Utfordringen er at dette kan sende signaler til samfunnet generelt og til personer med slike tilstander spesielt (Asch 2000). Personer kan oppfatte det som fornærmende at «min tilstand er en akseptert abortgrunn», at «var det opp til samfunnet, var jeg heller død», «jeg er lite verdt», eller de kan oppfatte seg diskriminert. Mens generell abort er uspesifikk, er NIPT for bestemte tilstander spesifikk (Asch 2000).

Med NIPT vil langt flere grupper kunne komme til å oppfatte seg som «utrydningstruet», slik som Marte Wexelsen Goksøyr (Downs syndrom) (2011) og Bjørn Hatterud (rygggmargsbrokk) (2007). Så lenge fosterdiagnostikken var forbeholdt svært alvorlige tilstander, slik som trisomi 13 og 18, var det ingen som sto frem og erklærte seg truet eller utryddet. Det er først når man kan teste for tilstander taleføre personer har, at signaleffekten oppdages som en utfordring. En gruppe som også kan illustrere problemet, er døve. Ved identifisering og fjerning av fostre med genetisk betinget døvhet, kan døve personer komme til å føle at deres (tegn)språkfellesskap er truet, og at døve personer kan ende opp isolerte og ensomme. Døve har brukt slike argumenter mot cochleaimplantat (eller mot manglende tegnspråkopplæring ved bruk av slike implantat) og vil på samme grunnlag kunne argumentere mot NIPT. ${ }^{10}$

Selv om UNNs søknad gjelder å erstatte KUB med NIPT, argumenteres det fort for å utvide testingen til lavrisikogrupper (Skogstrøm 2013). Mye tyder på at utviklingen av testene vil gå mot stadig flere og mildere tilstander - tilstander som personer har, som kan oppfatte og formidle sine oppfatninger.

\section{Signaleffektens etikk}

Hvordan skal vi tenke om det at enkeltpersoner og grupper opplever å bli fornærmet, krenket og diskriminert av at deres tilstand er gjenstand for fravalg gjennom fosterdiagnostikk og abort? Da dette er en problemstilling som kommer opp i full bredde med NIPT, og som i mindre grad har vært fremme i den norske debatten, fortjener spørsmålet litt ekstra oppmerksomhet.

Det argumenteres for at tilbudet om fosterdiagnostikk for spesifikke tilstander er et uttrykk for at personers liv vurderes og bedømmes av utenforstående som et liv det ikke er verdt å påbegynne (Gillam 1999), og som at tilstanden utgjør en grunn for abort (Andersson et al. 2008). Diskrimineringen skjer ved at helhetsvurderinger gjøres på bakgrunn av bestemte egenskaper:

As with discrimination more generally, with prenatal diagnosis, a single trait stands in for the whole, the trait obliterates the whole. With both discrimination and prenatal diagnosis, nobody finds out about the rest. The tests send the message that there's no need to find out about the rest. (Parens \& Asch 2000, s. 13)

Vi får en slags pars pro toto-effekt ved at personen kjennetegnes (reduseres) til en egenskap.

Berge Solberg argumenterer for at signaleffekten er sterkest der tilstanden er knyttet til identitet, som ved Downs syndrom, og mindre uttalt ved andre tilstander, som cystisk fibrose, ryggmargsbrokk og Huntingtons sykdom. Personer med Downs syndrom repre- 
senterer en annerledeshet, der personen og diagnosen er nærmere knyttet til hverandre (Solberg 2008). Dersom dette er riktig, kan det forklare de opphetede diskusjonene om KUB (som i hovedsak oppdager fostre med Downs syndrom) samt hvorfor UNNs søknad om å erstatte KUB med Downs-spesifikk NIPT er spesielt utfordrende. Solbergs poeng er at fosterdiagnostikk uttrykker en negativ holdning til, og potensielt også diskriminering av, personer med tilstandene, men at det $\mathrm{i}$ hovedsak handler om identitetsrelaterte tilstander, som Downs syndrom. Problemet er at også personer med ryggmargsbrokk føler seg «utryddingstruet» (Hatterud 2007), selv om ryggmargsbrokk ikke knyttes til identitet, slik som ved Downs syndrom.

Ved å knytte fornærmelsen, krenkelsen eller diskrimineringen til intensjonen hos den som velger bort fostre, og diagnoseidentiteten hos den rammede, overser (eller underkjenner) man viktige sider ved signalargumentet. Også andre enn personer med Downs syndrom kan oppfatte det krenkende og diskriminerende at denne tilstanden regnes som abortgrunn. Eksempelvis reagerer mange pårørende sterkt på fosterdiagnostikk. ${ }^{11}$

Det kan selvsagt hevdes at krenkelsen er de krenkedes subjektive oppfatning, og at denne oppfatningen ikke stemmer overens med oppfatningen til individer som velger å la seg teste, og som fjerner fostre med den aktuelle tilstanden. De ønsker verken å krenke eller utrydde noen. De ønsker seg friske eller «normale» barn (Solberg 2008). Like fullt er det slik det oppfattes av personer med slike tilstander, enten det er fordi de føler at samfunnet minner dem på at de er annerledes, at de plages av tanken på at dersom deres foreldre hadde hatt den muligheten man har i dag, ville de selv kanskje ikke eksistert, eller at de kjenner på den holdningen som uttrykkes ved at noen velger å fjerne fostre som har (genetiske) egenskaper som assosieres med deres egen tilstand. De føler seg krenket og/ eller diskriminert. Hva kan vi gjøre med det?

Et av svarene på dette har vært at personer med tilstander som vi søker etter, kan bli fornærmet, men at de ikke er diskriminert (de Jong et al. 2011; Gillam 1999). Om de fornærmes, men ikke diskrimineres, svekkes signaleffektargumentet. Det er uklart om så er tilfelle. Dersom det blir færre personer av en gitt tilstand, kan det selvsagt resultere i mer ressurser til de som er igjen, men det kan også bety mindre kompetanse, ressurser og oppmerksomhet for personer med tilstanden og følgelig en diskriminering sammenlignet med andre tilstander med samme grad av alvorlighet eller funksjonsnedsettelse. Følelsen av diskriminering er reell, selv om den kan vise seg å være mer eller mindre (eksternt) begrunnet.

Selv om vi tar argumentet om at NIPT bare vil føre til fornærmelse, men ikke diskriminering, på alvor, kan vi få problemer. Er det akseptabelt («bare») å fornærme personer som har en mer eller mindre alvorlig sykdom eller funksjonsnedsettelse? Vi er ellers svært forsiktig med å fornærme personer som vi antar er sårbare. Eksempelvis er vi varsomme med å diskutere abort både offentlig og privat av frykt for å såre eller fornærme personer som har fătt utført abort. Hvis det er tilfelle, må det være en moralsk relevant forskjell på personer med ulike funksjonshemminger og personer som har tatt abort, siden førstnevnte må akseptere å bli fornærmet av våre ordninger (og handlinger), mens sistnevnte blir vist hensyn til ved at man unngår å diskutere abort i deres nærvær. Alternativt må vi kunne diskutere abort mer åpent. 
Det kan også argumenteres med at det ikke er noen intendert eller målrettet fornærmelse ved spesifikk fosterdiagnostikk, slik som NIPT, og at fornærmelsen derfor ikke kan tas alvorlig. Verken det enkelte paret som velger NIPT og abort som følge av dette, eller samfunnet som tilbyr dette, har som intensjon å fornærme noen. Man undersøker og fjerner fosteret på bakgrunn av fosterets genetiske egenskaper og ikke på grunn av egenskaper eller kjennetegn ved levende personer. Men grunnen til at man fjerner fostre, er ikke fosterets genetiske egenskaper. Problemet er ikke det ekstra kromosomet (i trisomi), men de egenskapene eller tilstandene dette kan medføre dersom fosteret får vokse og barnet bli født. Vurderingen baserer seg altså ikke på egenskapene til det enkelte fosteret, men på egenskapene og tilstanden hos personer som lever. Når vi som samfunn, individ eller par velger å la fosteret undersøke for bestemte (genetiske) tilstander, er det nettopp levende personer som har disse tilstandene, vi har i tankene. De genetiske egenskapene som assosieres med tilstandene, har de fleste av oss ikke noe forhold til. Derfor finnes det grunnlag for å hevde at det finnes en rettethet fra den eller de som velger, mot den eller de som lever og har tilstanden.

Hvordan vi skal håndtere signaleffekten er et vanskelig moralsk spørsmål (om hva skal vi gjøre) som knytter an til etiske utfordringer (hvordan kan vi begrunne handlingsvalgene). NIPT aktualiserer og forsterker utfordringene fordi det blir mulig å teste (og fjerne fostre) for en lang rekke tilstander før grensen for selvbestemt abort.

\section{Hvordan unngå mulighetenes imperativ?}

Internasjonalt er det en tydelig tendens til å innføre tester før de er skikkelig evaluert (Health Council of the Netherlands 2008). Uttalensene om NIPT i det offentlige ordskiftet, som referert innledningsvis, indikerer at vi står ovenfor et mulighetenes imperativ (Hofmann 2002). At noe er mulig, eksempelvis å teste fosterets DNA/RNA i den gravide kvinnes blod, tilsier her at vi bør gjøre det. Dette er en klassisk feilslutning, der man slutter fra det deskriptive til det preskriptive - fra er til bør. Slike feilslutninger reduserer vår selvbestemmelse, ved at løsningen er gitt av omstendighetene, men det reduserer neppe vårt ansvar (Hofmann 2002).

På samme måte som vi bør være oppmerksomme på (og unngå) verdiladede termer i debatten om NIPD, ${ }^{12}$ bør vi unngå feilslutninger og føringer. Farene ved skråplansargumentet og det automatiske fremskritt-argumentet har allerede vært nevnt. En åpen debatt om vanskelige spørsmål bør bestrebe seg på å fri seg fra føringer, slik som mulighetenes imperativ, i størst mulig grad.

\section{Det statsliberale dilemma}

En annen utfordring er det som har blitt kalt «det statsliberale dilemma», det vil si der «summen av ønskede individuelle valg, på paradoksalt vis, fører til uønskede (og uintenderte) konsekvenser for storsamfunnet» (Nielsen 2003: 43, Nielsen 2005). Mens den enkelte legitimt ønsker seg barn uten lyte og sykdom, kan det tenkes resultatet blir et samfunn der flere føler seg krenket og diskriminert, eller der det blir mindre «plass til 
alle», slik det står i formålsparagrafen til bioteknologiloven. Man er eksempelvis bekymret for hvilke holdninger og normer fosterdiagnostikk vil gi, og for fellesskapets normer. Det er selvsagt vanskelig å forutse hvilket samfunn man vil få i fremtiden (som følger av individuelle valg). Dessuten kan det statsliberale dilemma oppfattes deterministisk: Negative holdninger vil (med nødvendighet) bre seg som følge av individuelle valg, og vi bør derfor begrense slike valg. Den motsatte og mer normdannende varianten tilsier at vi må gripe inn og forme samfunnet så vi ikke får holdninger som samfunnet ikke er tjent med, eksempelvis at personer med funksjonshemminger eller deres pårørende krenkes eller diskrimineres. Her er det ikke slik at vi underkastes holdninger i samfunnet, men at vi aktivt former dem $\mathrm{i}$ tråd med våre idealer.

I bunnen av det statsliberale dilemma ligger en bekymring om at dersom liberaliteten opphøyes til absolutt prinsipp, vil den forvandles til illiberalitet (Skjervheim 1968).

\section{Diskusjon}

De etiske utfordringene med fosterdiagnostikk generelt og NIPT spesielt er et stort og omfattende tema. En fullstendig behandling av temaet lar seg vanskelig fange inn i en enkelt artikkel. Jeg har derfor måttet gjøre et utvalg. En rekke temaer har ikke blitt drøftet, og mange temaer har bare blitt overfladisk behandlet. Valget kan åpenbart kritiseres. Jeg har valgt å vie mindre oppmerksomhet til områder som er godt og grundig drøftet tidligere, og viet mer oppmerksomhet til temaer som har blitt lite debattert.

Enkelte vil også kunne hevde at jeg maner til omkamp, da jeg tar opp igjen mange av temaene som er drøftet i forbindelse med andre former for fosterdiagnostikk, og som har funnet sin løsning tidligere (Hov, Åsberg \& Torstensen 2014). Her er poenget at når man gjør en vurdering av de etiske utfordringene ved en teknologi, er det hensiktsmessig å undersøke og gjøre rede for utfordringene ved den teknologien den bygger på (fosterdiagnostikk) og grenser til (KUB) (Hofmann 2005). Dessuten kan ny teknologi kaste nytt lys over gamle problemstillinger. Om argumentene var gode tidligere, vil de også holde vann i dag (Hofmann 2013c).

Artikkelen gir dessuten ikke noen klar vurdering av om NIPT er bra eller dårlig, og den gir ikke klare råd om hva vi bør gjøre. Det skyldes delvis at målsettingen har vært å forklare hvorfor myndigheten ikke enkelt og greit erstatter KUB med NIPT. Hensikten har vært å identifisere og belyse vanskelige moralske spørsmål for gjennom dette å legge til rette for en åpen og transparent offentlig debatt. Målet er derfor ikke å gi konkrete svar eller argumentere for bestemte løsninger (Hofmann 2005). Etikere har ikke nødvendigvis forrang til å komme med konkrete løsninger fremfor andre i offentlige diskurser (Nagel 1987; Elster 2007; Cowley 2012). Vi kan identifisere og analysere moralske utfordringer slik at legitime beslutningstagere har et best mulig åpent og transparent grunnlag for å fatte beslutninger. 


\section{Konklusjon}

Med NIPT vokser betydningen av kvinners blod, og muligheten til å bestemme fosterets egenskaper øker dramatisk. NIPT gir oss nye individuelle valg. Men valgene kan bli vanskelig å forstå og å ta. NIPT (gjen)reiser grunnleggende etiske spørsmål som abort, moralsk status og kriterier for fravalg og alvorlig sykdom. Disse gjelder for mange former for fosterdiagnostikk. I tillegg reiser NIPT flere spesifikke spørsmål, slik som det fremtidige barnets autonomi og rett til privatliv og konfidensialitet. Muligheten til å foreta reproduktive valg kan bli sterkt utvidet med NIPT, både fordi man kan teste for en lang rekke nye tilstander, og fordi testene kan tas innenfor grensen for selvbestemt abort. Samtidig er valgmulighetene begrenset til fravalg, og man har (foreløpig) et begrenset antall fostre å velge fra, slik at «designerbaby»-problematikken ikke synes reell. Dessuten vil de(n) enkeltes valgmulighet kunne begrenses av tilgang til god informasjon og veiledning, men også av føringer som ligger i tilbudet av helsetjenester («forventede valg»).

Et av de spørsmålene som fortjener ekstra oppmerksomhet, er hvorvidt NIPT kan føre til at personer og grupper blir fornærmet, trakassert eller diskriminert. Det er en viktig problemstilling, fordi fravalgspørsmålet baserer seg på kjennskap til egenskaper hos levende mennesker (og ikke genetiske egenskaper ved fostre) og fordi NIPT utvider muligheten av å teste for en lang rekke tilstander, hvor personene som har disse tilstandene, vil være langt bedre i stand til å oppfatte seg som diskriminert og rope «utrydningstruet» enn barn med trisomi 13 og 18.

Spørsmålet om å innføre NIPT reiser derfor en rekke grunnleggende etiske utfordringer som ikke har enkle og samlende løsninger. Det kan forklare hvorfor det ikke har vært lett for helsemyndighetene å svare på spørsmålet om hvorvidt NIPT bør erstatte KUB. Men det tilsier også at vi bør ta oss tid til en grundig diskusjon om hvorvidt og eventuelt hvordan NIPT skal innføres i Norge. De spørsmålene som denne artikkelen har identifisert, er:

1 Hvilke kriterier skal gjelde for at man skal kunne lete etter og fjerne fostre med bestemte tilstander? (Hva er det ved tilstandene som kvalifiserer til fravalg?)

2 Hvor sikre må vi kunne være på at gitte testresultat gir bestemte egenskaper hos fødte personer for å kunne akseptere fravalg?

3 Hvordan skal vi håndtere genetisk informasjon om fostre som kan utvikle seg til levende personer? (Hvordan skal våre behov for kunnskap om genetisk informasjon hos fostre veies opp mot retten til kunnskap/uvitenhet for fremtidige mennesker?)

4 Hvordan skal vi forhindre at mennesker som har de tilstandene som velges bort, blir fornærmet, krenket eller diskriminert?

5 Hvordan skal vi forhindre at vi gjennom aktivt fravalg av ulike tilstander utvikler holdninger og normer i samfunnet som bryter med verdier som likeverd og idealer om «et samfunn med plass til alle», i henhold til bioteknologiloven $₫ 1$ ?

Svarene på spørsmålet om testenes nøyaktighet gir oss ikke svar på disse spørsmålene. Vi må kjenne testenes prediktive verdier, men det forteller oss ikke hvilke fostre som skal velges bort. Vi kan ikke gi etiske spørsmål vitenskapelige svar. 


\section{Noter}

${ }^{1}$ Interessekonflikter: Forfatteren har vært med på å utrede de etiske aspektene ved ultralyd i Kunnskapssenterets rapporter $(2008,2012)$. Han har også vært medlem av Sosial- og helsedirektoratets referansegruppe for biofaglige spørsmål (2007-2010). Hofmann har vært medlem av Preimplantasjonsdiagnostikknemnda fra 2010. Han er spesielt interessert i verdispill i forbindelse med innføring av ny bioteknologi og er særlig opptatt av skjulte og nedtonede verdier i tillegg til mangel på åpenhet og transparens i beslutningsprosesser om bioteknologi.

${ }^{2}$ Dennis Lo var den første til å oppdage cellefritt føtalt DNA i kvinnelig plasma i 1997 og har senere vært ledende i å utvikle non-invasiv prenatal diagnostikk.

${ }^{3}$ Metoden som brukes med å finne og analysere føtalt DNA eller RNA i gravide kvinners blod, omtales som non-invasiv prenatal diagnostikk (NIPD), mens de ulike mer eller mindre spesifikke testene som NIPD brukes til, omtales som non-invasive prenatale tester (NIPT). Selv om man kan diskutere etiske aspekter ved metoden (NIPD), drøfter denne artikkelen først og fremst etiske aspekter ved anvendelsen av NIPD til konkret NIPT.

${ }^{4}$ Kombinert ultralyd og blodprøve (KUB) er betegnelsen på en kombinert test der man med ultralyd måler nakkeoppklaring hos fosteret og med blodprøven måler ett hormon og ett protein (beta-hCG og PAPP-A). KUB gjøres gjerne i uke 11-13 i svangerskapet og inngår som en del av fosterdiagnostikk i Norge. Det tilbys til kvinner over 38 år, ved risikosvangerskap og i spesielle tilfeller til gravide i en vanskelig situasjon. Det har vært betydelig diskusjon og til dels opphetet debatt i Norge om å innføre KUB som et allment tilbud til alle gravide.

${ }^{5}$ Studier som viser testenes nøyaktighet for såkalte lavrisikogrupper har allerede begynt å bli publisert idet denne artikkelen går i trykken.

${ }^{6}$ Jeg skiller i denne artikkelen mellom moralske spørsmål, som handler om hvordan vi bør handle, og etiske utfordringer, som dreier seg om hvordan vi skal begrunne valg og handlinger.

${ }^{7}$ Med egenskap menes her kjennetegn og karakteristika generelt. NIPT gir kjennskap til genetiske egenskaper (genotype), men det er ikke disse egenskapene som er avgjørende for informasjonen til parene og deres valg, det er hvordan disse genetiske egenskapene kan arte seg hos et levende menneske (fenotype) som danner grunnlag for informasjon og valg.

${ }^{8}$ Norsk abortlov gir rett til selvbestemt abort frem til utgangen av svangerskapsuke 12. Etter uke 12 og til og med utgangen av svangerskapsuke 18 behandles søknad om abort av en egen abortnemnd. Etter utgangen av uke $18 \mathrm{og}$ frem til fosteret er levedyktig, gis det bare abort ved «særlig tungtveiende grunner». Fosteret regnes som levedyktig ved 22 fullgåtte svangerskapsuker.

9 Testene vil også kunne avdekke ny informasjon om fosterets slektninger.

${ }^{10}$ Jeg takker en av fagfellene som vurderte teksten, for dette eksemplet. Eksempelet er utfordrende hvis man bruker motstanden mot NIPT til å argumentere for at foreldre bør kunne hindre at barna får cochleaimplantat (slik fagfellen hevder). Her kan man argumentere for at det er en moralsk relevant forskjell mellom å behandle (eller ikke behandle) en eksisterende tilstand og å fjerne fostre og derved hindre eksistensen til barn med den samme tilstanden. I det første tilfellet er spørsmålet om en intervensjon er til beste for en eksisterende person med en gitt tilstand. I det siste tilfellet er det spørsmål om en person med en slik tilstand skal kunne bli født (eksistens).

${ }^{11}$ Mest uttalt og synlig er dette hos pårørende til personer med Downs syndrom.

${ }^{12}$ Slik som eksempelvis «non-invasiv» og «sorteringssamfunn».

\section{Referanser}

Andersson, A. et al. (2008) Våga tala klarspråk om fosterdiagnostik. Barometern, 24.1.

ANGELAB. (2012) A new genetic laboratory for non-invasive prenatal diagnosis. Lastet ned fra http://angelab-systems.eu/ 
Asch, A. (2000) Why I haven't changed my mind on prenatal diagnosis. I Prenatal Testing and Disability Rights, red. E. Parens \& A. Asch, s. 234-261. Washington: Georgetown University Press.

Bondevik, H. \& Lie, A.K. (2012) Rødt og hvitt. Oslo: Unipub.

Bratlid, D. (2007) Om uredelighet i norsk medisinsk forskning. Tidsskrift for Den norske loggeforening, 127 (13-14), s. 1795-1796.

Chitty, L.S. et al. (2012) Noninvasive prenatal testing for aneuploidy-ready for prime time? American Journal of Obstetrics and Gynecology, 206, s. 269-275.

Cowley, C. (2012) Expertise, wisdom and moral philosophers: a response to Gesang. Bioethics, 26 (6), s. 337-342.

de Jong, A. et al. (2011) Advances in prenatal screening: the ethical dimension. Nature Reviews Genetics 2011, 12 (9), s. 657-663.

Deans, Z. \& Newson, A.J. (2011) Should non-invasiveness change informed consent procedures for prenatal diagnosis? Health Care Analysis, 19, s. 122-132.

Dworkin, G. (1982) Is more choice better than less? Midwest Studies in Philosophy, 7, s. 47-61.

Ekelund, C.K. et al. (2008) Impact of a new national screening policy for Down's syndrome in Denmark: population based cohort study. BMJ, 337, a2547.

Elster, J. (2007) Hva skal vi med etiske komiteer? Etikk i praksis, 1 (1), s. 11-31.

Fan, H.C. et al. (2012) Non-invasive prenatal measurement of the fetal genome. Nature, 487, s. 320-324.

Gillam, L. (1999) Prenatal diagnosis and discrimination against the disabled. Journal of Medical Ethics, 25, s. 163-171.

Goksøyr, M.W. (2011) Vi er utrydningstruet. Morgenbladet, 8.4.

Greely, H.T. (2011) Get ready for the flood of fetal gene screening. Nature, 469, s. 289-291.

Green, J.M. et al. (2004) Psychosocial aspects of genetic screening of pregnant women and newborns: a systematic review. Health Technology Assessment, 8 (33), s. iii, ix-x, 1-109.

Hatterud, B. (2007) Jeg er av en utdøende rase. Aftenposten, 8.2.

Health Council of the Netherlands. (2008) Screening: between hope and hype. Health Council of the Netherlands, 2008. Lastet ned fra: http://www.gezondheidsraad.nl/sites/default/files/ 200805E_0.pdf

Helsedirektoratet (2013) De første oppdragene til metodevurdering. Lastet ned fra: http://helsedirektoratet.no/Om/nyheter/Sider/bestillinger.aspx

Helse- og omsorgsdepartementet (2013) Forslag til ny pasientjournallov og ny helseregisterlov. Høringsuttalelser. http://www.regjeringen.no/nb/dep/hod/dok/hoeringer/hoeringsdok/2013/ horing--forslag-til-ny-pasientjournallov/horingsuttalelser.html?id=731895

Henshall, C. et al. (2012) Using health technology assessment to support optimal use of technologies in current practice: the challenge of «disinvestment». International Journal of Technology Assessment in Health Care, 28 (3), s. 203-210.

Hofmann, B. (2002) Is there a technological imperative in health care? International Journal of Technology Assessment in Health Care, 18 (3), s. 675-689.

Hofmann, B. (2005) Toward a procedure for integrating moral issues in health technology assessment. International Journal of Technology Assessment in Health Care, 21 (3), s. 312-318.

Hofmann, B. (2006) When means become ends: technology producing values. Seminar.net Media, technology and lifelong learning, 2 (2). Lastet ned fra: http://seminar.net/index.php/ volume-2-issue-2-2006-previousissuesmeny-114/66-when-means-become-ends-technologyproducing-values

Hofmann, B. (2013a) Forbedret fosterdiagnostikk? Tidsskrift for Den norske legeforening, 133, s. 2336.

Hofmann, B. (2013b) Lillebror ser deg. Forskningsetikk, 3, s. 23. 
Hofmann, B. (2013c) Bare testen, men ikke formålet. Tidsskrift for Den norske legeforening. 134 (3), s. 265-266. Lastet ned fra: http://tidsskriftet.no/article/3103954

Holm, S. \& Takala, T. (2007) High hopes and automatic escalators: a critique of some new arguments in bioethics. Journal of Medical Ethics, 33 (1), s. 1-4.

Hov, G.G., Åsberg, A. \& Torstensen, K. (2013) Kommentar. Tidsskrift for Den norske legeforening, 134 (3), 264-265. Lastet ned fra: http://tidsskriftet.no/article/3103954/

Kitzman, J.O. et al. (2012) Noninvasive whole-genome sequencing of a human fetus. Science Translational Medicine, 4, 137ra176

Kvande, L. (2008) Bilete av svangerskap - bilete av foster. Ultralyd-diagnostikk i norsk svangerskapsomsorg 1970-1995. Trondheim: NTNU.

Lo, Y.M. et al. (1997) Presence of fetal DNA in maternal plasma and serum. The Lancet, 350 (9076), s. $485-487$.

Lo, Y.M. et al. (1998) Quantitative analysis of fetal DNA in maternal plasma and serum: implications for noninvasive prenatal diagnosis. The American Journal of Human Genetics, 62 (4), s. 768-775.

Lo, Y.M. et al. (2010) Maternal plasma DNA sequencing reveals the genome-wide genetic and mutational profile of the fetus. Science Translational Medicine, 2, 61 ra91.

Lo, Y.M. (2012) Non-invasive prenatal diagnosis by massively parallel sequencing of maternal plasma DNA. Open Biology, 2 (6), 120086.

Morain, S., Greene, M.F. \& Mello, M.M. (2013) A new era in noninvasive prenatal testing. The New England Journal of Medicine, 369 (6), s. 499-501.

Nagel, T. (1987) Moral conflict and political legitimacy. Philosophy and Public Affairs, 16 (3), s. 215-240.

Nepomnyashchaya, Y.N. et al. (2013) Non-invasive prenatal diagnostics of aneuploidy using nextgeneration DNA sequencing technologies, and clinical considerations. Clinical Chemistry and Laboratory Medicine, 51 (6), s. 1141-1154.

Newson, A.J. (2008) Ethical aspects arising from non-invasive fetal diagnosis. Seminars in Fetal and Neonatal Medicine, 13, s. 103-108.

Nicolaides, K.H. et al. (2012) Noninvasive prenatal testing for fetal trisomies in a routinely screened first-trimester population. American Journal of Obstetrics and Gynecology, 207 (5), s. 374.e1-374.e6.

Nicolaides, K.H. et al. (2013) First-trimester contingent screening for trisomy 21 by biomarkers and maternal blood cell-free DNA testing. Ultrasound in Obstetrics and Gynecology, 42, s. 4150 .

Nielsen, T.H. (2005) Det statsliberale dilemma. Nytt Norsk Tidsskrift, 2, s. 198-211.

Nielsen, T.H. (2003) Human self-design og det statsliberale dilemma - er det frie valg en trussel mot samfunnsutviklingen? I Fosterdiagnostikk og verdier, red. S. Rogne, s. 41-43. Oslo: Bioteknologinemnda. Lastet ned 20.12.2013 fra: http://www.bion.no/filarkiv/2010/07/ 2003_10_31_fostediagnostikk_090304.pdf

NT 3. (2013) Flertall sier ja til Downs-blodprøve. Aftenposten 29.7. Lastet ned fra: http:// www.aftenposten.no/familie-og-oppvekst/Flertall-sier-ja-til-Downs-blodprove7266139.html

Nuffield Council on Bioethics. (2006) Genetic screening: a Supplement to the 1993 Report by the Nuffield Council on Bioethics. London: Nuffield Council on Bioethics. Lastet ned fra: http:// www.nuffieldbioethics.org/sites/default/files/files/Genetic\%20Screening\%20\%20a\%20Supplement\%20to\%20the\%201993\%20Report\%20(2006)(1).pdf

Papageorgiou, E.A. \& Patsalis, P.C. (2013) Maternal plasma sequencing: a powerful tool towards fetal whole genome recovery. BMC Medicine, 1 (1), s. 56. Lastet ned fra: http://www.biomedcentral.com/1741-7015/11/56 
Parens, E. \& Asch, A. (red.). (2000) Prenatal Testing And Disability Rights. Georgetown: Georgetown University Press.

Press, N. (2000) Assessing the expressive character of prenatal testing: The choices made or the choices made available? I Prenatal testing and disability rights, red. E. Parens \& A. Asch, s. 214234. Washington DC: Georgetown University Press.

Rafi, I. \& Chitty, L. (2009) Cell-free fetal DNA and non-invasive prenatal diagnosis. British Journal of General Practice, 59 (562), s. e146-148.

Røe, K., Salvesen, K.Å. \& Eggebø T.M. (2012) Blir retningslinjene for fosterdiagnostisk ultralyd fulgt? Tidsskrift for Den norske legeforening, 132, s. 1603-1606.

Rołnsvåg, S. (2013) Flertall vil avdekke Downs syndrom. Dagen. 29.7. Lastet ned fra: http:// www.dagen.no/2013/07/29/samfunn/kvinner/downs_syndrom/blodprove/153926

Salvesen, K.Á. (2014) Fosterdiagnostikk med blodprøver. Tidsskrift for Den norske legeforening, 134, s. 388-389.

Seror, V. \& Ville, Y. (2009) Prenatal screening for Down syndrome: women's involvement in decision-making and their attitudes to screening. Prenatal Diagnosis, 29, s. 120-128.

Skjervheim, H. (1968) Det liberale dilemma. I Det liberale dilemma og andre essays, s. 11-30. Oslo: Tanum.

Skogstrøm, L. (2013) Ny fostertest til vurdering: påviser Downs syndrom i 9. uke. Aftenposten 14.8 Solberg, B. (2008) Frykten for et samfunn uten Downs syndrom. Etikk i praksis. Nordic Journal of Applied Ethics, 2 (1), 33-52.

van den Berg et al. (2005) Are pregnant women making informed choices about prenatal screening? Genetics in Medicine, 7, s. 332-338.

van den Heuvel et al. (2010) Will the introduction of non-invasive prenatal diagnostic testing erode informed choices? An experimental study of health care professionals. Patient Education and Counseling, 78, s. 24e8.

Wright, C.F. et al. (2012) Non-invasive prenatal diagnostic test accuracy for fetal sex using cell-free DNA a review and meta-analysis. BMC Research Notes, 5, s. 476.

Wright, C. (2009) Cell-free fetal nucleic acids for non-invasive prenatal diagnosis. Report of the UK expert working group. PHG Foundation. Lastet ned fra http://www.phgfoundation.org/reports/ 4985 